\title{
Total salinity stress on physico-chemical characterization of lecithin isolated from soya bean oil seeds grown in the coastal region of south, India
}

\author{
Pragasam Antony ${ }^{\mathrm{a}, \mathrm{b}}$, Preeti N. Tallur ${ }^{\mathrm{a}}$, Sikandar I. Mulla ${ }^{\mathrm{c}}$, Vinayak M. Naik ${ }^{\mathrm{a}, \mathrm{b}^{*}}$ \\ ${ }^{a}$ Department of Chemistry, Govt. Arts and Science College, Karwar- 581301, Karnataka State, India. ${ }^{b}$ Research \& Development Centre, Bharathiar \\ University, Coimbatore -641046, Tamil nadu State, India. ${ }^{c}$ Department of Biochemistry, Karnatak University, Dharwad 580 003, Karnataka State, India.
}

\begin{tabular}{|c|c|}
\hline ARTICLE INFO & ABSTRACT \\
\hline Article history: & \multirow{9}{*}{$\begin{array}{l}\text { Phospholipid is very essential in the balanced diet. The vegetarian people in the coastal area are habitant of } \\
\text { using edible oil seeds as daily food grains. Salinity of water during cultivation decreases the accumulation of oil } \\
\text { content (12-15\%) in seeds. Present experiment was focused on total salinity and ionic stress on physiochemical } \\
\text { characterization of extracted lecithin from soya bean oil under saline and non-saline cultivations. The } \\
\text { experiment proves that the percentage of phospholipids in oil and lecithin is decreased by } 1.02 \% \text { and } 8.08 \% \text {, } \\
\text { respectively under saline cultivation. The phospholipids of the lecithin were qualitatively identified by thin-layer } \\
\text { chromatography (TLC) and high performance of liquid chromatography (HPLC). The } \mathrm{R}_{\mathrm{f}} \text { values for } \\
\text { phosphatidyl-ethanolamine (PE), phosphatidyl-serine (PS), phosphatidyl-inositol (PI) and phosphatidyl-choline } \\
\text { (PC) of samples were well related to the standard. HPLC spectrum is well resolved and the retention time (RT) } \\
\text { is correlated the standard with high precision. Quantisation of phospholipids shows a variation in the average } \\
\text { percentage of PC, PI, PS and PE as } 17.925,9.125,5.9,15.1 \text { for saline cultivation and } 22.25,12.025,8.525 \text {, } \\
18.975 \text { for non-saline cultivation. Average decrease in the percentage in saline cultivation is due to the total } \\
\text { salinity and ionic }\left(\mathrm{Na}^{+} \mathrm{Cl}^{-}\right) \text {stress of water. }\end{array}$} \\
\hline Received on: $25 / 05 / 2016$ & \\
\hline Revised on: 17/06/2016 & \\
\hline Accepted on: 10/07/2016 & \\
\hline Available online: $30 / 08 / 2016$ & \\
\hline Key words: & \\
\hline Phospholipids, Salinity and & \\
\hline & \\
\hline cultivation. & \\
\hline
\end{tabular}

\section{INTRODUCTION}

Vegetable materials usually contain only small amounts of phospholipids, ranging from 0.3 to $2.5 \mathrm{wt}$. \% (Wagner and Wolff, 1964).Phospholipids are complex lipids which contains one or more phosphate groups. Phospholipids are amphipathic in nature that is each molecule consists of a hydrophilic portion and a hydrophobic portion thus tending to form lipid bilayers (Dowhan and Bogdanov, 2002). In fact, they are the major structural constituents of all biological membranes, although they may be also involved in other functions such as signal transduction. The most abundant types of naturally occurring glycerol phospholipids are phosphatidyl-choline, phosphatidylethanolamine, phosphatidyl-serine, phosphatidyl-inositol, phosphatidyl-glycerol and cardiolipin. The structural diversity

* Corresponding Author

Email:naikvinayak54@yahoo.com within each type of phosphoglyceride is due to the variability of the head group, variability of the chain length and degree of saturation of the fatty acid ester groups. Phosphatidyl-choline Providesfree choline in the blood for the manufacture of acetylcholine which regulates digestive, cardiovascular and liver functions (Alvarez et al., 1997; Spiers et al., 1996). Phosphatidylcholine and Phosphatidyl-ethanolamine (80:20) is essentialfor the production of stable liposomes, anti-spattering agent in margarine. Phosphatidyl-serine is essential to the functioning of all body cell, supports brain functions that decline with age, memory enhancer (Kidd, 1996). In case of pure vegetarians, it is so essential to make up the phospholipid content having vegetables and edible oil grains in their balanced diet. The plant sources of phospholipids are soybean (Wagner and Wolff, 1964), rapeseed (Sosulki, 1981), sunflower (Litinova et al., 1971), cottonseed and peanut (Vijayalaxmi et al., 1969), ricebran (Adhikari and Adhikari, 1986), palm, coriander, carrot (Goh et al., 1982), papaya (Prasad et al., 1987), olive, barley, cucurbit (Schneider, 1989), corn, karanza, 
castor bean (Paulose et al., 1966), cocoa (Parsons et al., 1969), neem (Prasad et al., 1981), sesame, khakan (Prasad et al., 1979), pear, quince, tobacco (Zlatanov et al., 2000). Phospholipids are removed as by-product during the degumming process of vegetable oil refining.

Soybean seed is a major source of high-quality protein and oil for human consumption (Katerji et al., 2001). The unique chemical composition of soybean has made it one of the most valuable agronomic crops worldwide (Thomas et al., 2003). Its protein has great potential as amajor source of dietary protein. The oil produced from soybean is highly digestible and contains no cholesterol (Essa and Al-ani, 2001). Growth, development and yield of soybean are the result of genetic potential interacting with environment. Protein and oil content is related with environmental factors like moisture, temperature etc.

The 2002 U.S. soybean crop had an average protein (35.5\%) and oil (19.3\%)content because of hot and dry weather conditions in those areas contributed to poor yields (Brumm and Hurburgh Jr, 2002). Soybean seed production may be limited by environmental stresses such as soil salinity (Ghassemi-Golezani et al., 2009). Minimizing environmental stress will optimize seed yield (McWilliams et al. 2004). Soil salinity, resulting from natural processes or from crop irrigation with saline water, occurs in many arid and semi-arid regions of the world (Meloni et al., 2004). Salinity is a worldwide problem, affecting about 95 million hectares worldwide (Kazemghassemi-Golezani et al., 2010). The UNEP (United Nations Environment Program) estimates that 20\% of the agricultural land and $50 \%$ of the cropland in the world is salt-stressed (Yan, 2008).

Most of the salt stresses in nature are due to $\mathrm{Na}^{+}$salts, particularly $\mathrm{NaCl}$ (Demirel, 2005). High salinity lowers water potential and induces ionic stress, and results in secondary oxidative stress. It severely limits growth and development of plants by affecting different metabolic processes such as $\mathrm{CO}_{2}$ assimilation, oil and protein synthesis (Nasir khan et al., 2007). Present work is mainly focused on the variation of phospholipids content due to salt tress of salinity of water during cultivation of soybeans.

\section{MATERIALS AND METHODS}

\section{Chemicals}

2-Propanol, n-hexane, acetic acid and chloroform with highest purity (HPLC grade) were procured from Hi-Media. Methanol, acetic acid, sodium acetate, per chloric acid, ammonium molybdate, aminonaphtholsulphonic acid, potassium dihydrogen phosphate, petroleum ether and acetone with highest purity (AR grade) were procured from S.D. Fine and Merck.

\section{Collection of samples}

Four varieties of soy bean seeds were collected from coastal and non-coastal region of Karnataka, Tamil Nadu and Andhra Pradesh (India) available in the weekend market. The seeds were dried under sun light first and then kept at $90^{\circ} \mathrm{C}$ (about three hours) in an oven. Then these are fine powdered and used for the extraction of oil. The samples were labelled as soya bean-a, soya bean-b, soya bean-c and soya bean-d for saline (coastal) cultivation and soya bean- $a_{0}$, soya bean- $b_{0}$, soya bean- $c_{0}$, soya bean- $\mathrm{d}_{\mathrm{o}}$ for non-saline (non-coastal) cultivation.

\section{Extraction of oil}

$50 \pm 0.5 \mathrm{~g}$ of seed powder is packed and stapled in a Whatman grade no. 42 filtered paper. The packet is inserted into the middle piece of soxhlet extractor. Oil was extracted using petroleum ether for three hours. Petroleum ether was recovered and the oil was dried $85^{\circ} \mathrm{C}$ in a preheated oven for one hour. Oil obtained is cooled in a desiccator and weighed for constant weight.

\section{Extraction of Lecithin}

$5 \pm 0.2 \mathrm{~g}$ of fresh oil was dissolved in analytical grade acetone and stirred well. The insoluble lecithin was filtered and flushed with $\mathrm{N}_{2}$ gas. A feathery material was obtained which on drying in oven at $75-80^{\circ} \mathrm{Cforms}$ a reddish brown transparent solid. It was weighed for constant weight.

\section{High Performance Liquid Chromatogram (HPLC) analysis of phospholipids}

High Performance Liquid Chromatogram (HPLC) was recorded using Shimadzu LC-2010HT instrument series of wavelength range 190-600nm with bandwidth $8 \mathrm{~nm}$.Instrumental wavelength accuracy and wavelength reproducibility are $\pm 1 \mathrm{~nm}$ and $\pm 0.1 \mathrm{~nm}$. Lichrosorb, Si-60, $10 \mu \mathrm{m}\left(\mathrm{C}_{18}\right)$ column was saturated by 2-propanol and maintained at $30^{\circ} \mathrm{C}$. $10 \mu \mathrm{l}$ of the sample in mobile phase was programmed for injection and the mobile phase n-Hexane: 2-propanol: acetate buffer (8:8:1, v/v) was pumped at rate of $2 \mathrm{ml} / \mathrm{min}$ and chromatograms were recorded at $206 \mathrm{~nm}$.

\section{Quantization of lecithin}

Sample was prepared by dissolving $0.1 \pm 0.005 \mathrm{gm}$ of extracted lecithin in chloroform according official methods and recommended practices of the American Oil Chemists Society (ACOS, $4^{\text {th }}$ Edn 1990). Sample was prepared by dissolving $0.1 \pm 0.005 \mathrm{gm}$ of extracted lecithin in chloroform. Aliquot equivalent to $0.010 \pm 0.005 \mathrm{gm}$ was pipette into $30 \mathrm{ml}$ graduated test tubes and digested by adding $0.9 \mathrm{ml} 70 \%$ per chloric acid at 80 $90^{\circ} \mathrm{C}$ followed by $120^{\circ} \mathrm{C}$ and $150-180^{\circ} \mathrm{C}$ on sand bath. The colourless and clear solution in the test tube is cooled ad volume is made up to $2 \mathrm{ml}$. To this $7.0 \mathrm{ml}$ of distilled water, $1.5 \mathrm{ml}$ of $2.5 \%$ ammonium molybdate and $0.2 \mathrm{ml}$ aminonaphtholsulphonic acid were added. The test tubes were placed in boiling water bath for exactly $7 \mathrm{mins}$ and cooled for 20 mins. Then optical density was measured at $830 \mathrm{~nm}$ using UV- Spectrophotometer against the blank.

Calibration curve was plotted using AR potassium dihydrogen phosphate solutions having 1 to $5 \mu \mathrm{g}$ of phosphorus.

$$
\% \text { of phospholipids }=\frac{\mathrm{A} \times 30.97 \times 100}{\mathrm{~W} \times 1000 \times 1000}
$$


Where, $\mathrm{A}=$ Phosphorus content in $\mu \mathrm{g}$ from calibration curve

$\mathrm{W}=$ Weight of sample in $\mathrm{g}$ from the sample aliquot

$30.97=$ Converting factor for phosphorus into phospholipids

\section{TLC analysis of phospholipids}

TLC plates of size $20 \times 20 \mathrm{~cm} 0.2 \mathrm{~mm}$ silica gel coated glass plates were activated at $110^{\circ} \mathrm{C}$ for 1 hour. The developing solvent was Chloroform:methanol: Acetic acid: Water (25:15:4:2, $\mathrm{v} / \mathrm{v})$. Spots were identified by Iodine vapour and eluted by Chloroform.

An aliquot of $10 \mu \mathrm{g}$ of isolated lecithin dissolved in chloroform was spotted on TLC plates. Chromatogram was developed using the mobile phase Chloroform: Methanol: Acetic acid:Water (25:15:4:2, v/v). The condition was followed exactly as given by Skipski and others. The plates were dried at room temperature for $20 \mathrm{~min}$ after an average time of running for $1 \frac{1}{2}$ hours. Spots were identified by iodine vapour and encircled using sharp needle. When iodine vapour was completely evaporated, the silica gel was scrapped using razor, quantitatively transferred into centrifuging tubes and added $2 \mathrm{ml}$ chloroform. It was mixed well, centrifuged and the centrifugates were collected in labelled $30 \mathrm{ml}$ graduated test tubes. Extractions were repeated twice for each spots and collected together in test tubes. Finally the chloroform was evaporated and residues obtained were used for the determination of different phospholipids

\section{RESULTS AND DISCUSSION}

\section{Determination oil content}

Oil was extracted from four different variety soya bean seed powdered materials by soxhlet extraction method. Seed powdered material contains $0.9-1.5 \%$ moisture. Average percentage of oil recovery from soya bean seeds grown in coastal and non-coastal cultivation by soxhlet extraction method is reproducible and regressive. Oil content per seed decreases in the coastal cultivation due to salinity stress.

Table 1: Average percentage of oil content in different cultivation under saline and non-saline cultivation.

\begin{tabular}{ccc}
\hline Variety of & \multicolumn{2}{c}{ Coastal Cultivation } \\
\cline { 2 - 3 } soya bean & Average weight (g) & Average Oil Content (\%) \\
\hline Soya bean-a & 50.40 & 18.03 \\
Soya bean-b & 50.10 & 18.07 \\
Soya bean-c & 50.10 & 17.91 \\
Soya bean-d & 50.00 & 18.15 \\
\hline & \multicolumn{2}{c}{ Non Coastal Cultivation } \\
\hline Soya bean- $\mathrm{a}_{\mathrm{o}}$ & 50.22 & 20.02 \\
Soya bean- $\mathrm{b}_{\mathrm{o}}$ & 50.14 & 19.87 \\
Soya bean- $\mathrm{c}_{\mathrm{o}}$ & 50.08 & 20.18 \\
${\text { Soya bean- } \mathrm{d}_{\mathrm{o}}}$ & 50.15 & 20.27 \\
\hline
\end{tabular}

The Table1 correlates oil accumulation in soya bean seeds where coastal cultivation gives 18.04 per cent and that of non-coastal cultivation is $20.13 \%$ oil which relates literature value $21.38 \pm 0.6 \%$ reported by American Soybean Association (Brumm and Hurburgh Jr, 2002). The recovery of oil shows linearity with regression $\mathrm{R}^{2}$ equal 0.0667 for coastal and 0.5996 for non-coastal cultivation (Fig. 1).

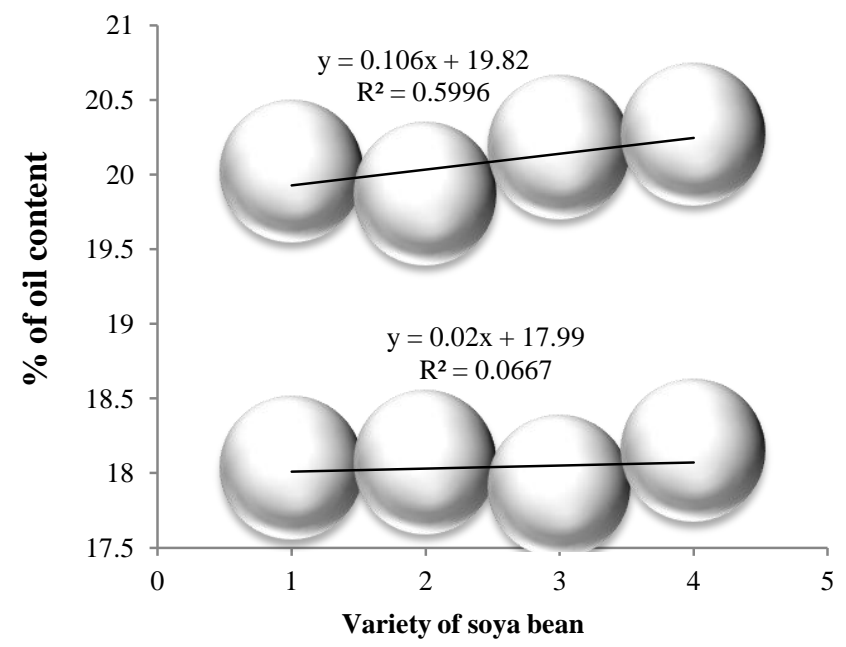

Fig. 1: Percentage of oil content soya bean for coastal and non- coastal cultivations.

Seeds from non-coastal cultivation have oil accumulation of $2.09 \%$ more than the seeds from coastal cultivation. This deterioration in oil content is caused by salt out effect of $\mathrm{NaCl}$ on soya proteins. Present work was focused on saline and non- saline condition of water for the cultivation of soya bean. Sea shore famers are dependents of saline water and faces saline stress.

\section{Analysis oil and Lecithin for phospholipid content}

Phospholipid content in oil and lecithin was determined by estimating the amount of phosphorus by per chloric acid digestion method using Official methods and recommended practices of the American Oil Chemists Society.

Amount of phosphorus in oil and Lecithin was estimated against sample aliquot weight. Table 2 lists the reproduce able results of the phospholipid content of soya bean oil and lecithin under saline, non-saline cultivation. The phospholipid content of oil and lecithin for soya beans in saline cultivation is relatively lesser compare to soya bean seed oil grown in non-saline cultivation.

Amount of phosphorus was determined by recording optical density using standard calibration curves (Fig. 2) thereby determining the percentage of phospholipid content of in and lecithin. Phospholipid content for oil and lecithin in saline (coastal) cultivation is $2.91 \%$ and $59.64 \%$ as compare to Non-saline (non-coastal) cultivation having $3.93 \%$ and $67.72 \%$. These results reveal that the salinity of water is the main cause for deterioration of oil content of soya bean seeds. Saline stress on growing soya bean results in decrease of oil content and phospholipid content per seed. 
Table 2: Amount of phosphorus, Average percentage of phospholipid in soya bean oil and lecithin under saline, non-saline conditions.

\begin{tabular}{|c|c|c|c|c|c|c|c|c|}
\hline \multicolumn{9}{|c|}{ Coastal cultivation } \\
\hline \multirow[b]{2}{*}{$\begin{array}{l}\text { Variety of } \\
\text { soyabean }\end{array}$} & \multicolumn{4}{|c|}{ Soya bean oil } & \multicolumn{4}{|c|}{ Acetone Insoluble Matter (AIM) } \\
\hline & $\begin{array}{c}\text { Wt. in } \\
\text { aliquot (g) } \\
1 \times 10^{-4}\end{array}$ & $\begin{array}{l}\text { Optical } \\
\text { Density }\end{array}$ & $\begin{array}{l}\text { Phosphorus } \\
\text { content in } \mu \mathrm{g}\end{array}$ & $\begin{array}{c}\text { Average \% of } \\
\text { phospholipid }\end{array}$ & $\begin{array}{c}\text { Wt. in } \\
\text { aliquot (g) } \\
1 \times 10^{-4}\end{array}$ & $\begin{array}{l}\text { Optical } \\
\text { Density }\end{array}$ & $\begin{array}{l}\text { Phosphorus } \\
\text { content in } \mu \mathrm{g}\end{array}$ & $\begin{array}{l}\text { Average \% of } \\
\text { phospholipid }\end{array}$ \\
\hline Soya- bean-a & 5.31 & 0.053 & 0.51 & 2.97 & 1.01 & 0.202 & 1.94 & 59.49 \\
\hline Soya- bean-b & 5.60 & 0.054 & 0.52 & 2.84 & 0.99 & 0.200 & 1.92 & 60.10 \\
\hline Soya- bean-c & 5.26 & 0.052 & 0.50 & 2.94 & 1.03 & 0.205 & 1.97 & 59.25 \\
\hline Soya- bean-d & 5.69 & 0.055 & 0.53 & 2.88 & 0.98 & 0.197 & 1.89 & 59.73 \\
\hline \multicolumn{9}{|c|}{ Non-Coastal cultivation } \\
\hline Soya- bean-a & 4.48 & 0.051 & 0.49 & 3.39 & 0.89 & 0.203 & 1.95 & 67.90 \\
\hline Soya bean-b & 4.58 & 0.053 & 0.51 & 3.45 & 0.95 & 0.213 & 2.05 & 66.98 \\
\hline Soya- bean-c & 4.30 & 0.050 & 0.48 & 3.46 & 0.94 & 0.215 & 2.07 & .68 .03 \\
\hline Soya- bean-d & 4.60 & .054 & 0.52 & 3.50 & 0.90 & 0.206 & 1.98 & 67.96 \\
\hline
\end{tabular}
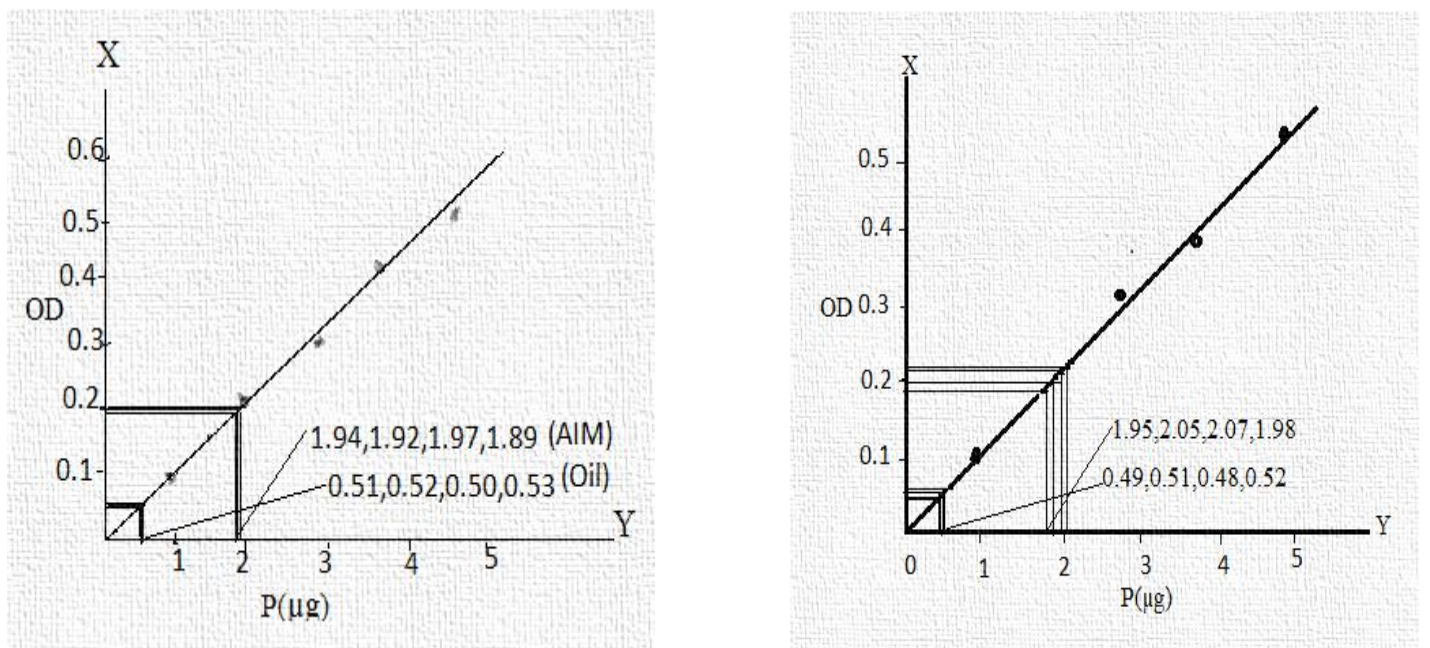

Fig. 2: Calibration curve for phosphorus content, in saline cultivation (a) and non-saline cultivation (b).

\section{Qualitative identification of phospholipids Lecithin Thin Layer Chromatography (TLC)}

Fig. 3 gives one dimensional TLC of isolated lecithin (AIM) and the standard commercial lecithin of purity $35 \%$ against PC. The spots were identified as PE, PS, PI, and PC in comparison with the standard on exposing to iodine vapour in iodine chamber.

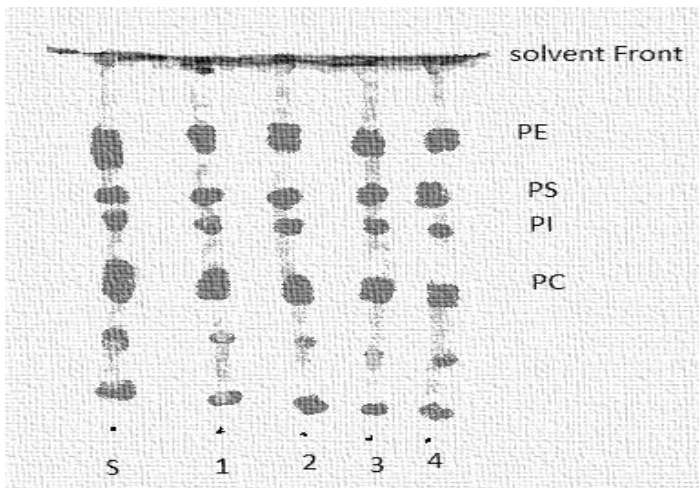

Fig. 3: TLC spots of phospholipids for standard and samples.

$\mathrm{R}_{\mathrm{f}}$ values of each spot was determined as ratio of the distance travelled by solvent (solvent front) to the distance travelled by the spots and related with the standard.
Table 3 correlates the $\mathrm{R}_{\mathrm{f}}$ of the samples and the standard. The $\mathrm{R}_{\mathrm{f}}$ value of PE 0.912 , PS 0.835 , PI 0.794 , PC 0.670 are well correlated with an average $R_{\mathrm{f}}$ value samples as $0.914,0.834,0.788$ and $0.671 . R_{f}$ values of sample are precisely correlated with the standard and have high accuracy with negligible deviation.

Table 3: $R_{f}$ values of Phospholipids of standard and samples.

\begin{tabular}{cccccc}
\hline \multirow{2}{*}{ Phospholipids } & \multicolumn{5}{c}{$\mathbf{R}_{\mathbf{f}}$ values } \\
\cline { 2 - 6 } & $\mathbf{S}$ & $\mathbf{1}$ & $\mathbf{2}$ & $\mathbf{3}$ & $\mathbf{4}$ \\
\hline PE & 0.912 & 0.918 & 0.912 & 0.906 & 0.918 \\
PS & 0.835 & 0.829 & 0.829 & 0.835 & 0.841 \\
PI & 0.794 & 0.788 & 0.788 & 0.794 & 0.782 \\
PC & 0.670 & 0.676 & 0.670 & 0.665 & 0.672 \\
\hline
\end{tabular}

\section{High Performance Liquid Chromatography (HPLC)}

The identification of different phospholipids was further confirmed by HPLC. Fig. 4 gives relatively comparable chromatograms. Retention time of each phospholipid was well related and resolved. Table 4 lists retention time for each phospholipids and correlates the chromatograms of the standard and the samples. 
Table 4: HPLC Retention time for PE, PA, PI and PC of soya lecithin.

\begin{tabular}{cccc}
\hline Phospholipid & $\begin{array}{c}\text { Retention Time } \\
\text { (Standard) Min }\end{array}$ & $\begin{array}{c}\text { Retention Time } \\
\text { (Coastal cultivation) } \\
\text { Min }\end{array}$ & $\begin{array}{c}\text { Retention Time } \\
\text { (Non-Coastal } \\
\text { cultivation) Min }\end{array}$ \\
\hline PE & 4.64 & 4.65 & 4.63 \\
PA & 2.71 & 2.73 & 2.73 \\
PI & 3.59 & 3.61 & 3.62 \\
PC & 8.03 & 8.07 & 8.07 \\
\hline
\end{tabular}

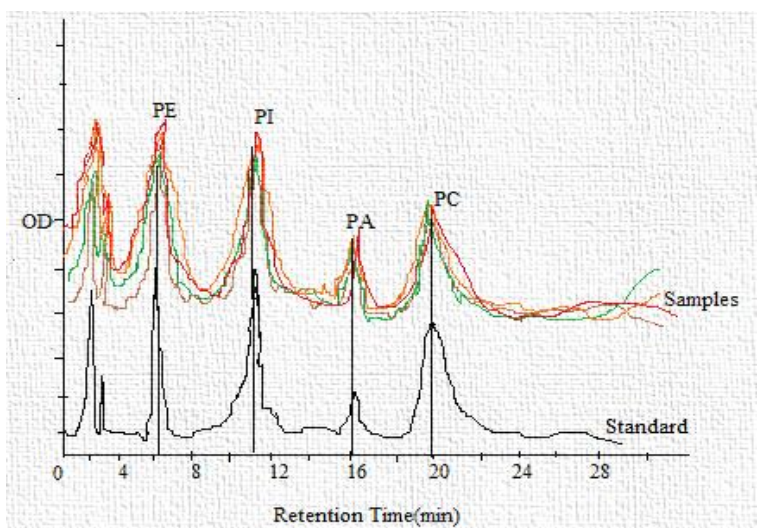

Fig. 4: HPLC of Soya Lecithin (a) Standard and (b) Samples from saline and non- saline cultivation.

\section{Quantization of Phospholipids in Lecithin}

An aliquot containing $10 \mu \mathrm{g}$ of each sample of lecithin in chloroform was spotted quantitatively on TLC plate and the spots were identified by iodine vapour (Fig. 5). Corresponding spots were marked using a sharp needle and silica gel was removed using razor after the complete elimination of iodine vapour adhere to the silica gel.

The phospholipids were quantitatively estimated by the experimental procedure. Table 5 summarises the relative percentage of PC, PI, PS and PE in the lecithin isolated from different variety of soya bean seeds obtained from saline and nonsaline cultivations. Quantitative determination of Phospholipids by TLC gives an average percentage of PC, PI, PS and PE as 17.925, $9.125,5.9,15.1$ for saline cultivation and 22.25, 12.025, 8.525, 18.975 for non-saline cultivation. The relative percentage of phospholipids in non- saline cultivation is higher than the saline cultivation.

The main cause for the decrease in the phospholipids content is the salinity and ionic $\left(\mathrm{Na}^{+} \mathrm{Cl}^{-}\right)$stress due to sodium chloride on accumulation of oil and phospholipids content. High concentration of total salt in water decreases the nitrogen fixation

Table 5: TLC quantisation of phospholipids of soya bean lecithin for saline and non-saline cultivation.

\begin{tabular}{|c|c|c|c|c|c|c|c|c|c|}
\hline \multicolumn{10}{|c|}{ Coastal Cultivation } \\
\hline \multirow{2}{*}{ Soya bean } & \multirow{2}{*}{$\begin{array}{l}\text { Wt. of PL in aliquot } \\
\qquad 1 \times 10^{-4}\end{array}$} & \multicolumn{4}{|c|}{ Phosphorus in Phospholipids ( $\mu \mathrm{g})$} & \multicolumn{4}{|c|}{ Percentage of Phospholipids } \\
\hline & & PC & PI & PS & PE & PC & PI & PS & $\mathbf{P E}$ \\
\hline Soya bean-a & 1.20 & 0.72 & 0.36 & 0.23 & 0.60 & 18.2 & 9.3 & 5.9 & 15.5 \\
\hline Soya bean-b & 1.10 & 0.63 & 0.32 & 0.22 & 0.53 & 17.8 & 8.9 & 6.1 & 14.8 \\
\hline Soya bean-c & 1.05 & 0.60 & 0.31 & 0.19 & 0.51 & 17.6 & 9.1 & 5.7 & 15.1 \\
\hline Soya bean-d & 1.07 & 0.63 & 0.32 & 0.20 & 0.52 & 18.1 & 9.2 & 5.9 & 15.0 \\
\hline \multicolumn{10}{|c|}{ Non-Coastal cultivation } \\
\hline Soya bean- $\mathrm{a}_{\mathrm{o}}$ & 1.04 & 0.75 & 0.41 & 0.29 & 0.63 & 22.2 & 12.1 & 8.5 & 18.8 \\
\hline Soya bean-bo & 1.12 & 0.82 & 0.43 & 0.30 & 0.70 & 22.6 & 11.9 & 8.3 & 19.3 \\
\hline Soya bean-c $c_{o}$ & 1.14 & 0.81 & 0.45 & 0.31 & 0.69 & 21.9 & 12.2 & 8.4 & 18.7 \\
\hline Soya bean- $d_{o}$ & 1.20 & 0.86 & 0.46 & 0.35 & 0.74 & 22.3 & 11.9 & 8.9 & 19.1 \\
\hline
\end{tabular}
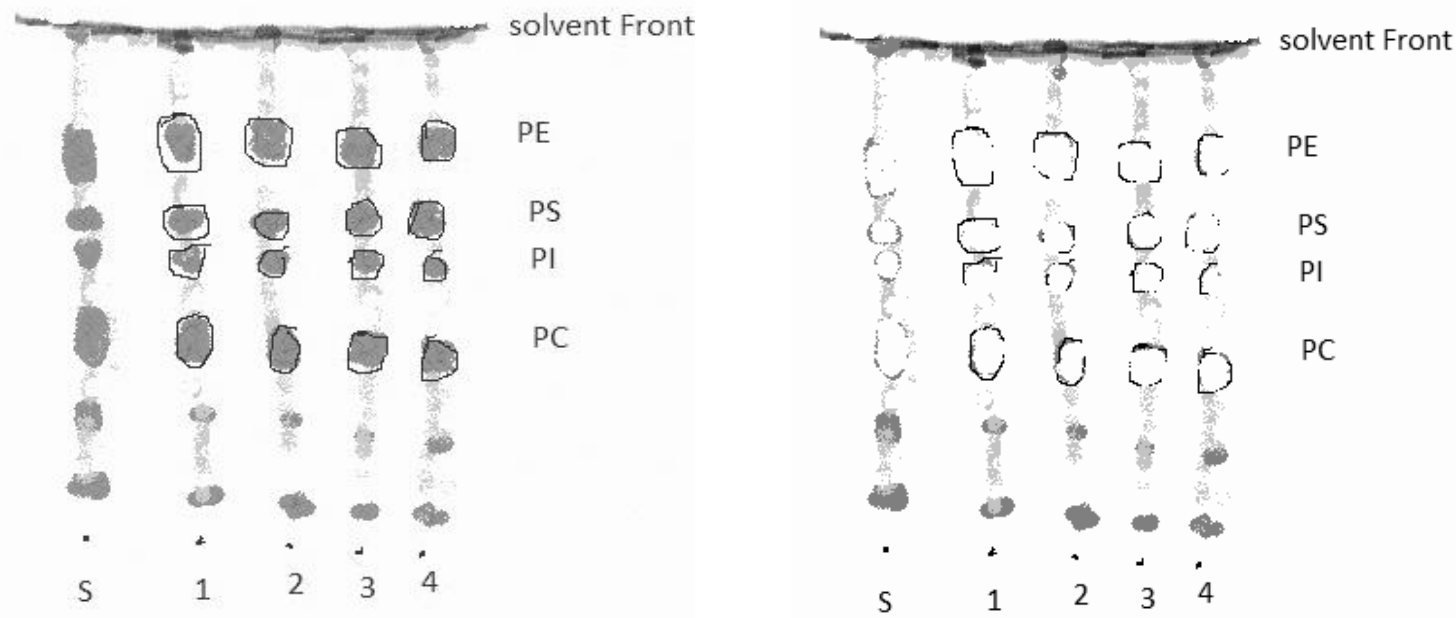

Fig. 5: (a) TLC spots for phospholipids after exposing to iodine vapour and (b) TLC spots for phospholipids after the removal of silica gel. 
and salting out the protein accumulation. The overall results evidences the salinity stress adversely affects the accumulation of phospholipid percentage in the soya bean oil seeds.

\section{CONCLUSION}

Present work was focused on salinity stress for the cultivation of soya bean under saline and non-saline conditions. Four varieties of soya bean seeds from coastal and non-coastal cultivation were analysed for oil and phospholipid content. The experimental result proves that the non-saline (Non-coastal) cultivation have higher oil and total phospholipid content $(20.09 \%$ and $67.72 \%$ ) than the saline (coastal) cultivation $(18.04 \%$ and $59.64 \%$ ). The experiment was also conducted for qualitative identification of individual phospholipids (PC, PI, PS and PE) by one dimensional TLC and HPLC spectrum. The spectral results were well related with the standard and the quantisation of phospholipids by TLC gives that the individual phospholipid content for non-saline cultivation is higher than that of saline cultivation. In summary, the overall results contribute to novelist of the experiments that the total ionic and salinity stress causes a decrease in total and individual phospholipid contents of soya bean seeds.

\section{CONFLICT OF INTEREST}

The authors declare that they have no conflict of interest.

\section{ACKNOWLEDGMENTS}

The authors are greatly indebted to University Grant commission who has given financial support and also thankful to the Principal of Govt. Arts and Science College, Karwar, for providing necessary facilities to carry out this research work.

\section{REFERENCES}

Adhikari S, Adhikari J. Indian rice bran lecithin. Journal of the American Oil Chemists Society, 1986; 63:1367-1369.

Alvarez XA, Laredo M, Corzo D, Fernandez-Novoa L, Mouzo R, Perea JE, Daniele D, Cacabelos R. Citicoline improves memory performance in elderly subjects. Methods and findings in experimental and clinical pharmacology,1997; 19:201-210.

Brumm TJ, Hurburgh Jr, CR. 2002. Quality of the Soybean Crop from the United States. Report to the American Soybean Association.

Dowhan W, Bogdanov M. 2002.Functinonal Roles of lipids in membranes, in: D. Vance, J.E. Vance (Eds.) Biochemistry of lipids, Lipoproteins and Membranes Elsevier Science.

EssaTA, Al-Ani DH. Effect of salt stress on the performance of six soybean genotypes. Pakistan Journal of Biological Sciences.2001; 4:175-177.

Ghassemi-Golezani K, Taifeh-Noori M,. Oustan S, Moghaddam M, Seyyed-Rahmani S. Oil and protein accumulation in soybean grains under salinity stress, Notulae Scientia Biologicae. 2010; 2:64-67.

Goh SH, Koh HT, Gee PT. Phospholipids of palm oil (Elaeisguineensis) J Am Oil Chem Soc,1982; 59:296-299.

Katerji N, Van Hoorn JW, Hamdy A, Mastrorilli M, Oweis T, Erskine W. Response of two varieties of lentil to soil salinity. Agric. Water Management, 2001; 47:179-190.
Kazem G-G,Minoo T-N, Shahin O, Mohammad M, Sadjad S-R. Oil and Protein Accumulation in Soybean Grainsunder Salinity Stress. Not SciBiol,2010; 2:64-67.

Kidd P. Phosphatidyl serine; membrane nutrient for memory. A clinical and mechanistic assessment. Alt Med Rev,1996; 1:70-84.

Litinova ED, Arisheva EA,Arutynnyan NS.Phospholipids of sunflower oil. Maslo-Zhir Prom,1971; 37:13.

McWilliams DA, Berglund DR,Endres GJ. 2004. Soybean growth and management. North Dakota State University.University of Minnesota.

Meloni DA, Gulotta, MR, Martinez CA, Oliva MA. The effects of saltstress on growth, nitrate reduction and proline and glycine-betaine accumulation inProsopisalba.Braz J Plant Physiol, 2004; 16:39-46,

Nasirkhan MH, Siddiqui M, Masroor A, Khan Naeem M. Salinity induced changes in growth, enzyme activities, photosynthesis, proline accumulation and yield in linseed genotypes. World J Agric Sci, 2007; 3:685-695,

Official methods and recommended practices of the American Oil Chemists Society, $4^{\text {th }}$ Edn., AOCS, 1608 , Broadmoor Drive, Champaign/ Illinois-61826, USA 1990 (Reapproved 1993).

Parsons J, Keeney P, Patton S. Identification and Quantitative Analysis of Phospholipids in Cocoa Beans. J Food Sci, 1969; 34: 497-499.

Paulose M, Rao V, Achaya K. Nature of castor seed phospholipids. Indian Journal of Chemistry, 1966; 4:529-532.

Prasad R, Rao V. Phospholipid composition of Salvadora oleoides (Khakan) seeds. J. Oil Technol Assoc India, 1979; 11:35-38.

Prasad R, Rao V. Phospholipid composition of neem seeds. J Oil Tech Assoc India, 1981; 13:101-104.

Prasad R, Rao Y, Rao V. Phospholipids of Palash (Butea monosperma), Papaya (Carica papaya), Jangli Badam (Sterculia foetida), Coriander (Coriandrum sativum) and Carrot (Daucus carota) seeds. J Amer Oil Chem Soc, 1987; 64:1424-1427.

Schneider M.1989.In lecithins: Sources, Manufacture and Uses. American Oil Chemical Society Champaign III.109-130.

Sosulki P, Zadernowski R, BabuchowskI.Composition of polar lipids in rapeseed.J Am Oil ChemSoc,1981; 58:561.

Spiers PA, Myers D, Hochanadel GS, Lieberman HR, WurtmanRJ.Citicoline improves verbal memory in aging. Archives of neurology, 1996; 53: 441-448.

Thomas JMG,Boote KJ, Allen LH, Gallo-Meagher M, Davis JM.Seed physiology and metabolism: Elevated temperature and carbon dioxide effects on soybean seed composition and transcript abundance. Crop Sci, 2003; 43:1548-1557.

Vijayalaxmi B, Rao SV, Achaya KT. An analysis of yield components in safflower.FetteSeifenAnstrichmittel, 1969; 1:757.

Wagner $\mathrm{H}$, Wolff $\mathrm{P}$. Isolation and Analysis of Plant Phosphatides and SphingolipidesFetteSeifenAnstrichmittel.1964; 66:425.

Yan L. Effect of salt stress on seed germination and seedling growth of threesalinity plants. Pakistan J Bio Sci, 2008; 11:1268-1272.

Zlatanov M, Menkov N. Phospholipid and fatty acid composition of tobacco seeds.RostlinnaVyroba, 2000; 46:429.

How to cite this article:

Antony P, Tallur PN, Mulla SI, Naik VM. Total salinity stress on physico-chemical characterization of lecithin isolated from soya bean oil seeds grown in the coastal region of south, India. J App Pharm Sci, 2016; 6 (08): 030-035. 